\title{
Female Care Workers in Multiple Locations - Research at Multiple Sites Methodological Decisions, Multi-Sited Ethnography
}

\author{
Tünde Turai \\ Institute of Ethnology, RCH, Hungarian Academy of Sciences, Budapest
}

\begin{abstract}
The investigation of the integration of East-Central European nurses into global labour market excluded the possible analysis of a spatially well definable group at the beginning of the research project; therefore the application of a different method became necessary. These women move between not only home and a new place of residence abroad, but, depending on job opportunities and various life situations, live in a number of countries, changing sites. Consequently, it has seemed adequate to focus on the specific features of the subject matter and to choose sites of research accordingly.

For the study of migration it is a significant contribution of multi-sited ethnography, beyond the pragmatic novelty of methodology, i.e. the multiplication of sites, that transgressing the national and international interpretive framework, it opens up transnational dimension and draws attention to the fact that new entities (e. g. networks and sites) may come into being that rewrite the topography of migration. This method requires flexibility, creativity and shifts of technology. But how can this new type of information be managed? This is the level where it is worth stepping over from multiple fields to multiple sites, and search for the connection between the sites instead of the comparability of fields. The author of the article provides an interpretive framework for the understanding of participation of East-Central European women in global catering sector at various points of the phenomenon and it contributes to the exploration of the inner dynamics and logics.

In course of the ever-expanding field research integrating new sites it may become clear that the key to understand the phenomenon is not to be detected in locally available contexts, but, rather, in the study of the various aspects of the phenomenon. Data got into context due to glancing at the process at several sites. The sites formed context for one another to deepen understanding. Keywords: multi-sited ethnography, women's migration, global household industry, Eastern and Central Europe
\end{abstract}

I carried out research in Sălaj County (Romania) for my doctoral dissertation, traveling regularly between Budapest and Transylvania by minibus during the 2000s. Several scheduled services departed from the Népstadion coach station, and later from the Népliget coach station. In around 2005 to 2006, I became aware of changes in the traveling public. While those waiting for the bus with me had earlier been mostly men, 
especially younger men, now women, and in particular middle-aged and older women, began to appear. This trend became gradually more pronounced, until eventually it was scarcely possible to encounter what had previously been the "typical" passenger from the Transylvanian Hungarian minority. The social cross-section encountered among the minibus passengers hinted at a comprehensive transformation: the number of scheduled services decreased, women took the places of men, and there was a change in generation. Although every now and then I met passengers in their twenties or thirties, they had very little in common with the guest workers of the earlier period. They were people who lived permanently, or who had possibly settled, in Hungary, and who were traveling home to visit their parents, or passengers who were visiting Romania to see relatives and friends. In the case of the older passengers, I thought at first that they must be the parents of the large number of Transylvanian Hungarians who had moved to Hungary in the period following the change of political regime, and who were visiting their children's families. This speculation proved only partly true. However, the stories I heard on the minibus sketched a new social situation: work-related migration between Transylvania and Hungary had changed. The need for cooperation between the two regions had emerged in a new sector of the workforce, mobilizing a different social group. Instead of young men employed as seasonal workers in the building industry and agriculture, women undertaking the care of elderly people had taken their place on the international labor market. ${ }^{1}$

In terms of my personal research, this observation offered a new opportunity: the possibility arose to combine the two separate topics (migration and the older generation) of my previous research. In order to investigate this phenomenon, I submitted an application with my fellow sociologist, Zsuzsa Széman, in 2008. ${ }^{2}$ In the framework of this two-year research, we studied the care provided for the elderly by Transylvanian women in Hungary. During the work, new directions gradually emerged, and I eventually continued the research on my own, widening the perspective and the target group. From 2010, I began to visit Western Moldavia (Romania) once again, but whereas my main concern at the start of my career had been the historical consciousness of the Csángós (Hungarian-speaking people from Western Moldavia), I now wanted to observe and explore the impact of women's mass emigration in this region. ${ }^{3}$ They were leaving their country to work mainly in Italy, and, as in the phenomenon outlined briefly above, it was predominantly a male exodus during the one and a half decades that followed the change in political regime.

\footnotetext{
${ }^{1}$ Vilmos Tánczos reports on the experience he gained on buses in the 1990s, and the situation of Transylvanian guest workers in Hungary, in an ethnographical essay. During this period, it was mostly men who traveled in an attempt to find their place in the labor market of another country and in the hierarchically organized system of international relations (TÁNCZOS 1996).

${ }^{2}$ OTKA K76236. Project title: Migrants in the care of the elderly. Duration: April 2009 - March 2011.

${ }^{3}$ The fact that Western Moldavia is one of the biggest departure points in Romania has played a major role in its becoming a research destination. Dumitru Sandu's research also shows that, while the exodus from three major regions of Romania was relatively even until 2001, Western Moldavia subsequently became the most significant area of departure, from where inhabitants migrated mainly to Italy (SANDU 2006:18-20).
} 
However, as a result of the economic crisis in 2008 , the demand for foreign workers performing physical labor decreased, while demand for female migrants in the service industry and as household helpers increased. My resulting dilemma was how to compare mobility related to the care of the elderly in the relations between Transylvania and Hungary, and between Moldavia and Italy. Of course, a comparison of the experience obtained in two different fields can readily highlight illustrative parallels. However, I became increasingly convinced that it would be more appropriate not just to compare the two sets of collected data, but rather to interpret them in a global context. This decision led me to further research sites. I began to examine women's migration from Hungary, and, as a result, I made interviews not only in Budapest but also in rural areas, and I also had an opportunity to visit Burgenland (Austria). In Transcarpathia (Ukraine), I visited women (also from the Hungarian minority) working as care assistants for the elderly, which provided an excellent parallel with my investigations into Transylvanian women. In the autumn of 2010, I spent three months in Italy (Ancona, Marche region), where I undertook residential fieldwork among Romanian women. The following year, I continued the Romanian Moldavian fieldwork; I also managed to visit the Republic of Moldova, and in Chişinău I interviewed families that had become transnational as a result of female migration. At the end of 2011, I travelled to Israel, where I learned about migration and the care of the elderly among Hungarian women outside Europe. From 2012, I continued to study the integration of Central and Eastern Europe into the global care sector, and I observed how the map of the region is being re-drawn from this point of view, since, while movement within the region has decreased, Hungary has increasingly become a country of exit rather than a country of reception. My last major fieldwork abroad was in the United States, where I was able to observe Hungarians working in the overseas household care industry. ${ }^{4}$

The topic gradually unfurled as new issues brought me to new locations, and the research developed not so much by forward planning, but rather step by step, through inspiration. The increase in the number of sites made the research increasingly rich, and the issues examined were also placed within a fruitful interpretative context in the course of the work, although at the same time tension began to mount. Since I had previously always dealt with one subject in one - in the broader or narrower sense, but locally coherent, that is, a single - site, and since the examples I had come across both in my professional context, in research carried out by others, and in the specialist literature I read, were also mostly based on the results of data collection in a single context, I began to wonder how I could obtain meaningful results while managing the combined knowledge gained from very different sites. My research work was already well on its way when I realized that the work that had evolved spontaneously was nothing other than the socalled multi-sited ethnographic method. Although the number of questions I had did not subsequently decrease, their focus changed, divergent thoughts were orientated, the collected data started to become complementary, and the observations began to connect.

\footnotetext{
${ }^{4}$ For this extensive fieldwork in various locations I received the following grants between 2008 and 2016, for various durations: Eötvös State Scholarship, Hungarian Academy of Sciences, János Bolyai Research Scholarship, Fulbright Research Scholarship.
} 


\section{FIELD CONCEPTS: MOVING FROM PLACE TOWARDS SITE}

Empowered by the principles and arguments of Malinowski, anthropology, the methodology of which makes it appropriate for the examination of small-scale, locally connected, closed communities, came up against the globalization of society, and the consequences of the post-colonial and postmodern transformation, to which new responses had to be given. In his famous study, George E. Marcus developed the methodological and theoretical foundations of multi-sited ethnography. In order to interpret contemporary phenomena, he considered it important to adopt an approach capable of following cultural changes, mobility and discontinuity. Instead of a world system, he proposed a more open, speculative, non-deterministic thematic development process, accompanied by the simultaneous construction of discontinuous contexts. Ethnography understood in this way does not aim at a holistic representation, but is a mapping strategy that seeks to identify relationships between different localities - that is, to position the internal logic of relationships, translations and associations. Research can no longer be static, because its subject is in permanent motion and embedded in different situations. In this way, it dissolves the tensions that arise from contrasting the "local" and the "global", "lifeworld" and "system", and suggests following "the people; things; metaphor; plot, story, or allegory; life or biography; conflict", and their parallel examination in multiple locations (MARCUS 1995).

During their analysis of the traditional concept of field in our profession, Akhil Gupta and James Ferguson show how the anthropological field and the research practice described/prescribed as fieldwork were established. In the course of their scientifichistorical overview, they highlight a process of fetishization, in which home and the place of research are separated, as are the researcher and the subject of the research - that is, the others. In this sense, the site is assumed to be an a priori defined world, with its different, other culture and group of people. On the basis of otherness, the world became conceptually hierarchical: the more other a particular culture was, the more valuable it was to research. Thus the ideal field is as different from the habitat of the researcher - who is mostly a member of Western civilization - as possible - that is, natural, rural, agrarian, stock farming, and, if possible, even savage. Since the field understood in this way has become a trademark of the profession and has played an important role in its institutionalization, the geographical idea of the field was firmly adhered to during the twentieth century. Gupta and Ferguson urged a move away from the conventional archetype of fieldwork, if only for the reason that in our closely related, interconnected world we are never out of the field, and the separation of field and home is completely artificial. This kind of separability of the field became possible only because the Western ethnocentric research circle generated the mystified ideas and habits by which it became other and was to be treated separately. The authors argue that the democratization of the discipline and the complexity of anthropological knowledge would be enhanced by replacing the fetishization of the field and fieldwork by flexible cognitive strategies, one (but not the only) alternative to which would be the examination of geographically definable areas (GUPTA - FERGUSON 1997).

At the same time as the above works, Arjun Appadurai was describing locality as one of the basic concepts of social research, in an attempt to bring about the necessary renewal. His ontological approach seeks an answer to the question "How does locality, 
as an aspect of social life, relate to neighborhoods as substantive social forms? [...] What can locality mean in a world where spatial localization, quotidian interaction, and social scale are not always isomorphic?" (APPADURAI 1996:179). In his imagination, a significant divergence in the concept of society is encouraged, as it separates locality from territorial constraints and geographical definition. In Appadurai's concept, locality is a formation, an aspect of social life: "I view locality as primarily relational and contextual rather than as scalar or spatial. I see it as a complex phenomenological quality, constituted by a series of links between the sense of social immediacy, the technologies of interactivity, and the relativity of contexts." (APPADURAI 1996:178)

Such thinking has opened the way for new questions, approaches and research directions. The relationship of researchers to the field has changed, the scope of research topics has been expanded, and the toolkit of research practice has become more varied. The self-reflexive attitude to the field underpinning the research has inspired the anthropological profession to clarify what can be further understood by the concept of the field, faced with the premise that space is socially constructed and that turning space into, or space becoming, field is not a given, but a product of research activity. Edited by Simon Coleman and Peter Collins, I would first like to mention the volume Locating the Field. Space, Place and Context in Anthropology, in which the authors seek to answer the question of how social processes can be described by a relativized, and by no means unambiguous, new concept of the field (COLEMAN - Collins 2006). A few years later, Mark Anthony Falzon, in his introduction to a major comprehensive volume of studies (edited by him), Multi-sited Ethnography. Theory, Praxis and Locality in Contemporary Research, simplifies the dilemma: "if space is produced", why would ethnographic space be an exception? For him, this is undoubtedly the deciding factor in the debate and makes it clear that contemporary societies are inevitably part of a larger entity, and that objects, people, information, goods and ideas are in constant motion, and, moving away from territorial constraints, they come closer to an open, global whole (FALZON 2009). Cordula Weißköppel focused her attention on how researchers piece together their research topic from the countless items of explored information, just like a puzzle. She considers her method not as target-oriented, but as situation-bounded, "focused" ethnography, and talks of "explicating the unseen connection between different research sites and their inherent data." (WeIsSKöppel 2009) Following Gupta and Ferguson's thoughts, James Clifford reached the conclusion that the field is not so much a space, but rather a habit: a set of dispositions and practices (CLIFFORD 1997, 2001). Since the field has become a place in the social sciences, the outlines of which are blurred, Eva Nadai and Christoph Maeder coined the phrase fuzzy fields to refer to sites that were formerly treated as concrete and delimited, reiterating that a definition made on a territorial basis necessarily requires a critical approach (NADAI - MAEDER 2005). It is also worth mentioning here the volume Where is the Field? edited by Laura Hirvi and Hanna Snellman, in which they argue that in a globalized world in which transportation has accelerated and mobility and mutual interrelatedness have increased, the non-Malinowskian treatment of the field has become essential (HIRVI - SNELLMAN 2012). Laura Hirvi, like the authors mentioned above, demonstrates the process by which the researcher achieves the final product - that is, the post hoc constructed field - by selecting subjects and data, and interacting with the investigated group and human contingency (HIRVI 2012). 
Marcus's work had a huge influence on the social sciences. It has proved particularly appropriate for migration research, where the parallel investigation of the exit and the reception space has already been highlighted, while this approach has opened the way for the more liberal and flexible selection of sites and their collective analysis. He also launched entirely new trends in the media sciences: we have since been able to talk about digital anthropology, netnography, cyber ethnography, online ethnography, and so on. Marcus succeeded in ensuring that multi-sited ethnography would not be regarded as a parasite only, a subordinate alternative to normative, mainstream anthropology, but as a fully fledged alternative, a parallel methodological approach, a para-site (MARCUS 2000). ${ }^{5}$

The method has not yet became part of Hungarian practice, and even the exact translation and adaptation of the terminology have yet to be determined. We find the term in scientific-historical surveys or methodological summaries, mostly in the form of "többterepü etnográfia" (VöRös - FRIDA 2004; FEISCHMIDT 2007; KISDI 2012). However, this translation is misleading with respect to the essence of the method, which is not merely about multiplying sites, or undertaking research at more sites. Several international authors have pointed out that multi-sited does not mean multi-local examinations. Fieldwork in multiple locations, multiple networks and communities is more than the mere accumulation of locations and does not end in the comparison of data collected at different locations (HanNerz 2003; Horst 2009; WeibKöPpel 2009). A better Hungarian equivalent for multi-sited ethnography ("többszinterü etnográfia") was used by Gábor Biczó and Károly Nagy, who also applied the method themselves (Biczó 2012; NAGY 2012). I continue to use this term in Hungarian, simply because it facilitates dissociation from geographical location and its full range of associations, and, without any additional explanation, allows for the inclusion of non-area-based groups such as those organized on Facebook.

\section{HUNGARIAN WOMEN SCATTERED THROUGHOUT THE GLOBAL CARE SECTOR}

My choice of topic excluded the possibility of analyzing a territorially well defined group at the beginning of my research, although, based on my previous work experience, I was qualified and trained primarily for this. Thus, I had to move away from the village towards the city, from the city towards the global, and from the physically determined field towards the trans-local and virtual dimensions. My previous strategies, such as interviews, the mapping of networks, and participant observation, remained valid techniques, although in a changed form, with their validity parameters and interpretability frameworks rethought. Moving away from locality involved leaving my comfort zone, but this was unavoidable, since I was investigating mobile women who were not only moving between two places - their home and their new place of residence abroad - but who may also have worked in more host countries, depending on job opportunities and their changing life situations. It therefore proved appropriate to adapt to the features of the

\footnotetext{
${ }^{5}$ Critics of the method include Ghassan Hage (2005), Matei Candea (2009), Joanna Cook, James LAIDLAW, and Jonathan MaIr (2009).
} 
selected topic rather than the territorial aspects, and to select and shape the conversation partners and research sites as a function of them.

It also made my job harder that the actors and their stories did not necessarily come together. In Israel and Italy, I had the opportunity to research a more-or-less coherent network of connections, which was trans-local, although its members met as members of a looser or tighter network. In addition, I met individuals who did not have much to do with one another, although sometimes there were friendly connections, or some temporary or occasional acquaintanceships. Despite my attempts to connect the fields, networks and individuals, it turned out to be a naively optimistic idea for many reasons. First of all, the sensitivity of the subject set its own limitations: due to the illegal or quasilegal nature of the work on the one hand, and the private aspects of women's migration and the transnational family on the other, many people refused to allow me to contact their employers, spouses, the persons they cared for, their carers, their children, etc. I would have liked, for example, to talk to the husbands who had been left at home, to see what they thought of the women's migration, how they organized their lives as fathers in this restructured family and household, how they positioned themselves in terms of their changed earnings compared to their higher-earning wives, how they saw the evolution of marital dynamics, etc., but I was categorically refused an interview with them, and my questions were dealt with in a few casual sentences. On the other hand, the practical aspects of the research work limited the possibility to follow the inherent dynamics of the subject. Since my data collection work is based on funding, my plans and concepts have to be adapted to the nature and expectations of the tendering systems. In other words, I was able to do fieldwork where and when I managed to obtain support, and I was able to spend as much time at a particular site as the tenderer approved. For example, I would have liked to link my fieldwork in the Csángó lands (Western Moldavia) with the examination of migration from there to Italy. My network near Bacău (Bákó) would have oriented me towards Northern Italy, but unfortunately, I was unable to find an Italian research institute with which the Hungarian body funding of my research work had a contract. This is how I ended up in Central Italy, where I collected very rich material among Romanian women, although I was unable to substantiate my well-justified concepts. Thus, I had to rely on the opportunities for multi-sitedness afforded by less organized, and sometimes spontaneous or sporadic data collection. Thus, in the case of the present research, it can be stated that the site was constructed post hoc as a result of complex cooperation and dialogue, and was formed by three important actors: the researcher, the researched subjects, and the supporter(s).

For migration researchers, multi-sited ethnography - beyond the pragmatic innovation of the methodology, that is, the multiplication of sites - has the potential to open up a transnational dimension by transcending national and international interpretative frameworks: they no longer look at migrants as people migrating from A to B, but as people moving in a more complex global space and network of relationships, the elements of which are organized not simply by adding the elements of the exit and the receptive space and society, but by the emergence of new formations (such as networks and sites) among the new parameters that rewrite the topography of migration (AMELINA 2010; PróNAI 2002). Most research is still linked to two locations, which are connected either to the origin and the reception societies, or to the two different exit sites (e.g. WeIBKöPPEL 2009; 
Gallo 2009; CRinIs 2012; HiRvi 2012), but may extend to several continents (LeONARD 2009). Cindy Horst categorizes migration research that uses multi-sited ethnography according to whether the research is carried out individually or in a team, simultaneously or step-wise, and whether the sites are matched or non-matched (HoRst 2009). To date, there has been only one example of the simultaneous and matched collection of data by a research team, a solution that is not guaranteed to be free of error (due, for example, to the different qualifications and personal skills of the researchers), but that resolves most of the dilemmas related to multi-sited ethnography. Led by Valentina Mazzucato, a team of 16 full-time research assistants worked in Ghana and Amsterdam, investigating 33 contact networks and keeping in touch with 115 subjects between 2002 and 2005 . Their results are impressive and convincing. Their work can be considered exemplary, although the high cost of the project, at half a million euros, is a serious barrier, meaning that few people are likely to follow their example (Mazzucato 2009). It is therefore preferable to consider the lessons learned from smaller-scale research involving more compromises, and to follow the positive examples that emerge from them.

\section{DOUBTS AND OPPORTUNITIES}

The aim of the multi-sited method is to expand the boundaries of ethnography, while naturally encountering new boundaries. It is generally attacked for three reasons: the depth of the fieldwork is questioned, its duration is regarded as inadequate, and there are doubts about the context of the collected data (HaGe 2005; CANDEA 2009; CooK et al. 2009).

Understandably, it is difficult to set aside ideas that have been attached to the foundations of one of the basic trends of the anthropological tradition for over a century. The vision, according to which our discipline is capable of describing a holistic, homogeneous and continuous system of cultures, is ultimately a diminishing ideal, nor does it inspire ongoing discussions, because it is merely an impression of the assumptions/expectations of a past era. This is not only because it is no longer possible to find static, closed, welldefined cultural groups, but also because our theoretical knowledge of culture questions its existence and interpretability in this way. We therefore have to content ourselves with treating the social groups and cultural phenomena at the focus of our research as fragmented and discontinuous entities, to find the appropriate methodological tools for this, and to integrate the rapid transformations, and even ambivalences (MARCus 1995; Hannerz 2009; Falzon 2009). Falzon rejects the demand for conventional depth by the fact that the people at the focus of the research do not experience this either, thus it is probably not the way things happen. He argues that the exploration of a broader but shallower world is in itself a possible form of deeper understanding. Instead of a grand, holistic ambition, a nonchalant way of "making the cut" can be a satisfactory compromise, if it is good enough (FALZON 2009). According to Cindy Horst, the purpose of multi-sited fieldwork is not to understand a complete, localizable culture, but rather to target transnational networks and currents. Multi-sited ethnography is unlikely to provide a dense description of an individual node, but rather guarantees the dense description of the network itself, its internal dynamics, and its interacting individuals, things, 
activities and meanings. The point is to follow the relevance of the topic (HoRst 2009). Geographical parameters do not provide a meaningful description of sites, but rather new topographies, such as the relationships and discontinuity generated in transnational practice (AMELINA 2010).

Discussion of the depth of research is closely related to the temporal factors of fieldwork. The multi-sited researcher will naturally spend less time in one place. Clearly, research carried out in a team, as in the case of Mazzucato and his colleagues, can get over this problem, although due to practical constraints there is still room for individual research. Hannerz considers the classic ideas of anthropology to be obsolete in terms of this aspect of fieldwork, too. The researcher's extended stay of one or two years in a particular field was an adaptation to an earlier social situation and dynamics. Nowadays, people can be understood without being observed throughout the year, because their actions and their cycles of activity no longer depend on the changes of season. They are no longer pedestrians, nor is their living space bound to a limited field, where the researcher might pitch a tent and be stationed for longer periods of time. Instead of real natives, we can study mobile individuals and phenomena influenced by other impacts (HANNERZ 2003). Several authors report that, where it proved impossible to collect data for a longer period in one place, their field knowledge deepened during repeated visits and on returning several times (HANNERZ 2009; WeibKÖPpel 2009; LeONARD 2009). So what is the optimal amount of time to spend in one place in order to obtain in-depth knowledge?

During my fieldwork, as I have mentioned, I was building step by step. "Spiraling ethnography" ${ }^{\prime \prime}$ would be the most appropriate term for the workflow that I implemented, the most important advantage of which was that, with the involvement of new sites, not only were new data and contributions linked to earlier research results, but understanding was also deepened.

At different locations, I encountered different opportunities, and, subsequently, different challenges. Rarely did I have the luxury of asking the largely theoretical question "How much time would be optimal to spend in this particular field?" since the inverse dilemma was rather: "How can I optimally use the available time, as defined by the sponsor?" Thus, I am able to report on fieldwork of very different lengths, which I tried to manage well, even though the boundaries felt somewhat narrow at times.

In my own environment, I am in fact constantly in the field. In and around Budapest, I can make interviews continuously, and there are no major limitations to participant observation. The subject may come up in the most unexpected situations, and from a conversation with a friend, a Facebook post, a journey in a full car, or a non-Budapestbased friend asking for accommodation, I can obtain insights about someone's mother or grandmother being looked after by a Transylvania woman, or about someone traveling to Vienna or London to take care of an elderly person, perhaps in order to be able to afford a mortgage, or to supplement her income as a language teacher, etc. In addition, I also became involved in the care network in a completely unexpected way, by being considered and treated by caregivers and the family members of those being cared for (or even the person being cared for themselves) as a hub in this network, as someone with

\footnotetext{
${ }^{6}$ The term comes from Cindy Horst. Horst 2009:123.
} 
potential as an employment "bureau". Caregivers thus often ring me when they have no work, to indicate that they have spare capacity, while those on the other side obtain my phone number when they need a caregiver. Of course, this mediation is accompanied by information, meaning that I am able to find out how successful the encounter is, how the cooperation is developing, how they deal with difficulties, which situations generate tensions, and how individual life paths develop when caregivers/carers change.

My fieldwork in Transylvania and Moldavia is somewhat different, although similar in many ways. While I do not stay at these sites continuously, I return regularly, thus the observations are continuous. For the most part, I have spent one or two weeks in different settlements (Csíkszereda/Miercurea Ciuc, Madéfalva/ Siculeni, Marosvásárhely/Târgu Mureş, Szék/Sic, Gyergyószentmiklós/Gheorgheni, Tusnádfürdö/Băile Tuşnad, Zilah/ Zalău, Szilágysomlyó/Șimleu Silvaniei, Margitta/Marghita, Bucharest, Bákó/Bacău, Lujzikalagor/Luizi-Călugăra) in recent years - that is, from 2008 onwards. On occasions that are not fieldwork, such as visits to my family and relatives, but most importantly during minibus trips, I also have the opportunity to gather information on the topic.

There are sites that I was able to visit only for a short time. I was able to spend one week only in Transcarpathia, Burgenland and Chişinău. This time limit naturally determined the range of data collected. On such occasions, I undertook intensive interviews, but was only able to talk to those who were at home during this brief period, and who decided to trust me. I had no opportunity to make multiple inquiries, to adapt to the availability of those being interviewed, or to win over important people who declined to answer my questions. I had limited ability to adapt the data collection to aspects relevant to the subject, and I had to accept that not all of them would be valid. In Chişinău, I had to confine myself to the networks that were available to my university colleagues within the city. I had to adapt to this flexibly, and in order to increase my chances of finding out something worthwhile in this short period of time I adapted my research questions accordingly: I tried to address the young adult children of families that had become transnational as a result of women's migration, who - with their own experience in mind - were about to make a decision about how to pursue their own local or global careers, and their concepts about starting a family. Thanks to my colleague, who had experience in fieldwork in Transcarpathia, I was able to obtain a relatively extensive sample, even within the tight framework, as he carefully and thoroughly prepared the paths for me, helped me to create the conditions for reconnaissance, and, by his constant comments, provided valuable additional knowledge for the interpretation of the data. ${ }^{7}$ In Burgenland, my fieldwork was limited to the close circle of a single person, the Lutheran priest. Since the people of Oberwart (Felsőor) were rather reserved and considered the topic to belong to the private sphere, I had the opportunity to talk only to those who were willing to open up, following the recommendation of the pastor. I considered it necessary to supplement this sample with data collection in Szombathely (Hungary), which is geographically located on the other side of the border and thus belongs to another country, although from the point of view of the topic, the two geographical areas can be considered as a single site.

\footnotetext{
${ }^{7}$ I would like to express my gratitude once again to Sándor Borbély and his family.
} 
My fieldwork in Italy was significantly different. I spent three months in Ancona, permanently observing a particular community in a geographically well defined and transparent location. Of all the sites, this presented the greatest similarity to classical anthropological fieldwork in terms of the framework, strategies, and process of collection. There were rituals of entry and exit, steps in acceptance, the definition/ attribution/maintenance, as well as the occasional blurring, of the role of the researcher, difficulties resulting from the confusion of roles, continuity of presence and observation, and opportunities for participation. I thus had the opportunity to repeat interviews, build confidence, encourage optimal networking from various perspectives, expand sensitive topics, find suitable sources of information for special issues, change focus, follow up the internal logic of the work, and monitor crisis situations arising from individual life situations.

My fieldwork in Israel was something of a mixture of all the above: it was not identical to any of them, but share many similarities with all of them. I spent three weeks in the country, mostly in Jerusalem and Tel Aviv, although I also managed to visit the surrounding rural settlements. This fieldwork began in a unique way. As I knew that I had little time at my disposal, I looked for opportunities to prepare for the work as well as possible. By chance - through the multiple intermediation of family and acquaintances - I met a caregiver working in Israel, who, as it turned out later, was the most important node in the Israeli Hungarian care network. Thanks to her astute and proactive personality, I managed to establish several Facebook contacts very quickly, and I had chatted and skyped with my new acquaintances before my trip. Interestingly, most of those chats were not initiated by me, but rather the women working in Israel were making friends with me, interested about who I was, my trip, and my plans there, or simply telling me about the beauty of Israel, especially the tourist attractions - we exchanged short, mostly superficial but still informative, messages in keeping with the genre of chatting.

Thus, when I arrived, I did not find myself in a strange world. I had thought I would be the one to initiate relationships and untangle the grid of networks, but in this case, the other side was more active than I had ever experienced. To my great surprise, the phone in my hotel room rang on the first night, and a woman wanted to talk to me. My newfound acquaintance - who was not a member of the caregivers' network, but had found out about my trip through other sources - subsequently called me regularly to ask about my latest experiences, comment on my observations, and deliver various bits of information. The chef at the hotel also knew about me in advance, as he had somehow found out about me through the caregivers' network, and since I was staying there by chance, I had regular company and a willing informant at breakfast. This dynamic remained quite typical throughout. While I was reaching out to people, they were also reaching out for me, even organizing joint trips and recreational programs. Although their approach was intensive, they were neither intrusive nor restrictive in terms of my work in any way. At all times I was able to shape the data collection situations according to my own points of view, and I chose my interviewees freely from the network of contacts that they had readily made accessible to me. We kept in touch even after I returned home: we continued to follow one another's lives via email, Facebook, and sometimes Skype. This collection situation, which was very special in many ways, created a unique research site: a virtual 
field was localized for a few weeks, and later became accessible and observable in a virtual dimension.

Finally, I would like to mention my work in the United States. I spent five months at the Woodrow Wilson International Center for Scholars research institute in the capital city. I was therefore able to make thorough observations primarily in Washington, although I also made interviews in Chicago, New York and New Jersey. Although I spent more time here than in Italy or Israel, I did not achieve the same depth in the course of my fieldwork. It was a large field (not only geographically), with significantly more network connections, a more scattered and more varied society of caregivers, with links and nodes that were more difficult to access, and relationships that were more difficult to follow up. The time available was too short to obtain more complex knowledge. I therefore consider the results achieved here as pilot research, which can serve as starting and reference points for building fieldwork at a later date.

Following this detailed presentation of my multi-sited fieldwork, it is clear that this method requires great flexibility and creativity, and a constant change in technique (see also Amelina 2010). It is also clear that the comparison of the knowledge acquired at the different sites cannot be the goal of the analysis. Especially since fewer conditions are available for comparability. Because of the different frameworks, I needed to apply different techniques: sometimes I did mostly interviews, on other occasions I had more opportunity to be present and observe, and sometimes I wrote detailed field logs, as this was the optimal form of data recording. At some sites, I am present constantly; some I return to; there are some where all connections were severed on my departure; and there are some where, although I left, there is continuous follow-up via digital communication. The focus of the interviews and the researcher's questions also changed in line with the possibilities. I also had to permanently shape the strategies for the positioning of the researcher and the formulation of the research subject in keeping with the site, since the approach to the research situation was entirely different in Transcarpathia, Oberwart, Chişinău, and New York. The roles attributed to the researcher were also very different, and this determined the nature of the conversation: in Italy, I was initially considered as a potential rival, and then as a journalist; in Israel, I was treated as a girlfriend/tourist; in Austria, I was a kind of Hungarian little sister, who was given help to obtain information about the relations between Hungarians in the West and Hungary; in Hungary, I am a scientific researcher who carries out some serious and official (and therefore sometimes suspicious) work for a nationally recognized institution; in Transcarpathia, I was a trouser wearer, occupying a higher place in the hierarchy, as I had arrived from the Hungarian capital, while sometimes I was labeled as a "token-Transylvanian"8; in Transylvania, I am simultaneously an insider and an outsider, a part of the "us" group, a neighbor, a friend, an acquaintance, a friend of a friend, the acquaintance of an acquaintance, etc., and an external observer, a Hungarian from Hungary who wants God knows what again, and who asks questions on non-official work there; and in the United States, I provided a temporary diversion for the Hungarian diaspora as an authentic new Hungarian arrival,

\footnotetext{
${ }^{8}$ From among the Hungarian minority groups living outside the borders of Hungary, Transylvanian Hungarians have the strongest ability to enforce their own interests. Compared to them, the Transcarpathian Hungarians feel relatively in the background. With this statement, they are expressing their animosity, and in some sense their rivalry.
} 
who, moreover, came from the more genuine Hungarian world of Transylvania (which they considered more traditional).

There is no need for a lengthy explanation about how these attributed meanings and roles generated very different attitudes, which meant that, during conversations, I had to overcome various difficulties in order to ask my questions and receive more open, fuller answers.

So we come to the fundamental problem: What can we do with the knowledge thus obtained, and how can it be managed simultaneously? This is the level at which it is worth moving conceptually from "multi-local" to "multi-sited", not looking at the comparability of fields, but finding and mapping the opportunities for interconnections among the sites. In the course of my work, I was able to view the participation of women from Eastern and Central Europe in the global care sector at different points of the phenomenon (and not only locations), and was able to gain an insight into its internal dynamics and logic. I was able to obtain an understanding of who it is that is going to one country or another, and why; what transnational channels are being used; the perspectives according to which they are orientated, and how these change them; how national labor and immigration regulations affect care giving and the opportunities for the female role; which cultural factors affect the status of household employees (and how); the formation of migration plans and paths in different frameworks; how care for the elderly is integrated into the household industry or nursing sector; what home and family mean on a transnational basis, etc.

All these aspects emerge when we consider the mobility of women in Eastern and Central Europe as part of a global trend. And although, within this global dimension, the examined caregiving circles are not necessarily linked directly to one another, a coherent world is still taking shape on the basis of common experiences, life situations, interpretations, meanings, and complex transnational networks.

Among the doubts concerning multi-sited ethnography, I mentioned as the third one the contextualization of the data, which is worth reflecting on at this point. During my ever-expanding field research, I traveled to new locations because I realized that the key to understanding the phenomenon was not to be found in locally available contexts, but rather by examining the various aspects of the phenomenon. My data were contextualized by observing the process at more than one site. Each site created contexts for all of the others, thus deepening understanding. This recalls Appadurai's interpretation of neighborhood, which highlighted the unique dialectic that, while neighborhoods require the contexts produced by the randomness of history, the environment and imagination, they also create such contexts themselves, thus neighborhoods generate the contexts of neighborhoods (APPADURAI 1996:186).

\section{FIELDWORK ON THE INTERNET}

I devote a separate section to fieldwork carried out virtually, since, due to its novel character, the issues raised require reflection.

There are two aspects to the question. On the one hand, how does the Internet become a site, bearing in mind its indefinite nature, its lack of physical parameters, its freedom, 
liberty, and licentiousness, its different rules of play and possibilities, its rapid changes, and its specific internal dynamics? On the other hand, how can the pieces of reality be connected in virtual space and places with territorial features into a field?

Many researchers have been inspired by this challenge, and numerous analyses have been written, among which I here highlight the ideas of Daniel Miller. In a work written jointly with Don Slater (The Internet: An Ethnographic Approach), they argue that the Internet is not an outside world, but is embedded in social structures and relationships. Virtuality is not independent of the realistic, physical world and space, thus it is not possible to treat the two separately. The Internet is not a new reality, but a new form of mediation, and virtuality makes possible communication techniques that create, rather than merely mediate, realities. They do not consider it productive to contrast online and offline life, or to treat them separately, and they strongly encourage anthropological research to move beyond this dichotomy (Miller and SLATER 2001). As the importance of the topic steadily grew, Daniel Miller, along with Heather A. Horst, proposed establishing a new trend ten years later - that of digital anthropology - based on the volume Digital Anthropology. In the introductory study, the editors call repeatedly for a departure from feelings of nostalgia or romance for the pre-digital world, and insist that digital techniques, like any other element of material culture, are "becoming a constructive part of what makes us human" (MiLler and Horst 2012). I would like to refer to two further studies, an analysis by Tom Boellstorff, and Daniel Miller's independent work, both of which refer to Facebook as a research site, which has become important to me. The studies describe its organic embeddedness in everyday life, with Miller concluding, on the basis of the example of migrant women in the Philippines, that Facebook has become a kind of second home for them, a place where they live out their social lives due to their secluded lifestyles (BoellstorfF 2012; Miller 2012).

As Ihave mentioned, in the course of my research Facebook has become unintentionally important due to the dynamics of the examined phenomenon and the specific way of life and self-organization of the observed community. I should point out that Facebook also came into play in other research, without the virtual dimension becoming a site. A four-year tri-border study conducted within the framework of the Institute of Ethnology of the Hungarian Academy of Sciences has recently ended. ${ }^{9}$ As a result, the number of my acquaintances on the social network has increased, as many contacted me on the network after we met, although the knowledge that has become available in this way has only supplemented the data that I collected in the physical field. I tended to read mainly personal, private, or sometimes job-related entries, but their community relevance and connection to my topic were minimal.

The Facebook activity of the Hungarian women working in Israel and the virtual organization of their relationships were so significant that in their case I experienced in reality the organic connection, and even the confusion, of online and offline life. When working with them, I therefore considered the research site as both a physical and a digital space and activity.

However, location-based fieldwork techniques, and fieldwork techniques based on face-to-face interaction cannot be fully transposed into the methodological toolkit of the

\footnotetext{
${ }^{9}$ See http://www.nti.btk.mta.hu/harmashatarok/index.html (accessed March 16, 2016).
} 
virtual site. I am thinking here primarily of the dilemmas generated by the data provider and the changes and alternative ways of shaping the relationship with him or her (cf. MARKHAM 2013), and, on the other hand, of some very important ethical issues. I became a Facebook acquaintance of several people many years ago, when I first visited Israel, and since I was tagged, I can constantly see entries, photos, and comments. How well do they remember that I met them/were interested in them in the quality of researcher? When I do not have with me - because I am invisible - my working tools, which make my role and the reason for/intention of my presence clearly visible, does it occur to any of them, before they post something, that a researcher is watching? They invited me to be part of their Facebook group, and I have remained a member ever since. A public member, but a passive one. I never write any entries, thus I remain silent and invisible. To what extent can this non-physical presence be regarded as participant observation? I believe that we can scarcely talk about participation in the absence of physical perceptibility. Even classically understood observer status requires interpretation in the case of a virtual site. The presence of an offline observer, even if maximally passive, has an impact on events due to their physical perceptibility, but the same does not apply to the online space: an online observer is more like a voyeur. But what are the ethical rules for a voyeur? How should a voyeur act when trying to be fair to his or her acquaintances? ${ }^{10}$ Although there are legally defensible research procedures, since they are not entirely reassuring from an ethical point of view I have decided not to incorporate knowledge that I have gained in this way directly into my research, and to act as in the case of a personal encounter, taking care not to disclose information that makes it possible to identify an individual.

I use the knowledge that has become available to me via Facebook exclusively to understand community dynamics and network operation - beyond the level of the individual - to help reinforce or refute the observations made during my brief fieldwork, and to confirm certain views and relationships.

\section{AND WHAT ABOUT THE ELEPHANT?}

Joanna Cook and her co-authors base their criticism of multi-sited ethnography on the parable about the blind men and the elephant - traditionally attributed to Buddha. According to this story, the king ordered all the men in his country who were blind by birth to be brought together, and after each of them touched just one part of the elephant, the king asked them what kind of thing an elephant was. Those who touched its head replied that it was like a pot. Those who had held its ears thought it resembled a winnowing basket. Those who had felt its trunk talked of a plough, and so on. Then the blind men began to quarrel. The authors point out that the parable is a warning against jumping to conclusions about the nature of reality based on partial insights, and they draw a parallel with the methodology of multi-sited ethnography. They doubt that the

\footnotetext{
${ }^{10}$ Facebook refers to this in Section 5, Point 7, of its Statement of Rights and Responsibilities: "If you collect information from users, you will: obtain their consent, make it clear you (and not Facebook) are the one collecting their information, and post a privacy policy explaining what information you collect and how you will use it." https://www.facebook.com/legal/terms/update (accessed March 16, 2016).
} 
parts can lead to any kind of totality, and argue that with the multiplication of sites, only the scale is increased, not the quality of the research and knowledge (CoOK et al. 2012).

Well, I don't know whether an elephant exists or not. Nevertheless, I have been able to experience, during multi-sited research, that it points beyond the exploration of multiple sites. It outlines something bigger, a phenomenon that exists in some wider space. The exploration of several sites provides more than a possibility to compare and accumulate partial information. The spirally built fieldwork has led to higher correlation, even if not to the cognition of completeness.

\section{REFREENCES CITED}

Biczó, Gábor

2012 Szempontok az etnikai együttélés egyensúlyi helyzeteinek elméletéhez [Aspects towards a Theory of Equilibria in Ethnic Coexistence]. Kultúra és Közösség, series IV, 3(3-4):23-35.

BoelLSTORFF, Tom

2012 Rethinking Digital Anthropology. In Horst, Heather H. - Miller, Daniel (eds.) Digital Anthropology, 39-60. London - New York: Berg.

CANDEA, Matei

2009 Arbitrary Locations: In Deference of the Bounded Field-site. In Falzon, Mark-Anthony (ed.) Multi-Sited Ethnography. Theory, Praxis and Locality in Contemporary Research, 25-46. Farnham - Burlington: Ashgate.

CLIFFord, James

1997 Spatial Practices: Fieldwork, Travel, and the Disciplining of Anthropology. In GuptA, Akhil - Ferguson, James (eds.) Anthropological Locations. Boundaries and Grounds of a Field Science, 185-222. Berkeley - Los Angeles - London: University of California Press.

Coleman, Simon - Collins, Peter (eds.)

2006 Locating the Field. Space, Place and Context in Anthropology. Oxford - New York: Berg.

CooK, Joanna - LAIDLAW, James - MaIR, Jonathan

2009 What if There is No Elephant? Towards a Conception of an Un-sited Field. In Falzon, Mark-Anthony (ed.) Multi-Sited Ethnography. Theory, Praxis and CRINIS, Vicki Locality in Contemporary Research, 47-72. Farnham - Burlington: Ashgate.

2012 The Challenges of Fieldwork: Researchers, Clothing Manufacturers, and Migrant Workers. Journal of Social Issues in Southeast Asia 27(1):168-189.

FALzon, Mark-Anthony

2009 Introduction: Multi-Sited Ethnography: Theory, Praxis and Locality in Contemporary Research. In FALzoN, Mark-Anthony (ed.) Multi-Sited Ethnography. Theory, Praxis and Locality in Contemporary Research, 1-24. Farnham - Burlington: Ashgate. 
FEISCHMIDT, Margit

2007 Az antropológiai terepmunka módszerei [Methods of Anthropological Fieldwork]. In KovÁcs, Éva (ed.) Közössegtanulmány. Módszertani jegyzet, 223-233. Budapest - Pécs: Museum of Ethnography - University of Pécs, GALLO, Ester Faculty of Humanities, Department of Communication and Media Studies.

2009 In the Right Place at the Right Time? Reflections on Multi-Sited Ethnography in the Age of Migration. In Falzon, Mark-Anthony (ed.) Multi-Sited Ethnography. Theory, Praxis and Locality in Contemporary Research, 87102. Farnham - Burlington: Ashgate.

GatT, Caroline

2009 Emplacement and Environmental Relations in Multi-Sited Practice/Theory. In Falzon, Mark-Anthony (ed.) Multi-Sited Ethnography. Theory, Praxis and Locality in Contemporary Research, 103-118. Farnham - Burlington: Ashgate.

Gupta, Akhil - Ferguson, James

1997 'The Field' as Site, Method, and Location in Anthropology. In GuPTA, Akhil Ferguson, James (eds.) Anthropological Locations. Boundaries and Grounds of a Field Science, 1-46. Berkeley - Los Angeles - London: University of California Press.

Hage, Ghassan

2005 A Not so Multi-sited Ethnography of a Not so Imagined Community. Anthropological Theory 5(4):463-475.

HANNERZ, Ulf

2003 Being there... and there... and there! Reflections on Multi-Site Ethnography. Ethnography 4:201-216.

2009 The Long March of Anthropology. In FaLzon, Mark-Anthony (ed.) Multi-Sited Ethnography. Theory, Praxis and Locality in Contemporary Research, 271282. Farnham - Burlington: Ashgate.

HiRvi, Laura

2012 Multi-Sited Fieldwork amongst the Sikhs in Finland and California. Reaching the Offline via the Online. In Hirvi, Laura - Snellman, Hanna (eds.) Where is the Field? The Experience of Migration Viewed through the Prism of Ethnographic Fieldwork, 23-44. Studia Fennica Ethnologica.

Hirvi, Laura - Snellman, Hanna (eds.)

2012 Where is the Field? The Experience of Migration Viewed through the Prism of Ethnographic Fieldwork. Studia Fennica Ethnologica.

Horst, Cindy

2009 Expanding Sites: The Question of 'Depth’ Explored. In FaLzon, Mark-Anthony (ed.) Multi-Sited Ethnography. Theory, Praxis and Locality in Contemporary Research, 119-134. Farnham - Burlington: Ashgate.

Horst, Heather H. - Miller, Daniel (eds.)

2012 Digital Anthropology. London - New York: Berg. 
KISDI, Barbara

2012 A kulturális antropológia története, elméletei és módszerei [The History, Theories and Methods of Cultural Anthropology]. University handout. Budapest: Pázmány Péter Catholic University.

LAJOS, Veronika

2013 A modernitás eleganciája. A kritikai szembenézés társadalomtudományi gyakorlatának néhány aspektusa [The Elegance of Modernity. A Critical Approach to Some of the Aspects of Social Sciences Practice]. Kulturra és Közösség 4(4):43-54.

LEONARD, Karen Isaksen

2009 Changing Places: The Advantages of Multi-Sited Ethnography. In FAlzon, Mark-Anthony (ed.) Multi-Sited Ethnography. Theory, Praxis and Locality in Contemporary Research, 165-180. Farnham - Burlington: Ashgate.

Marcus, George E.

1995 Ethnography in/of the World System: The Emergence of Multi-Sited Ethnography. Annual Review of Anthropology, 24, 95-117.

2000 Introduction. In Marcus, George E. (ed.) Para-Sites. A casebook against cynical reason, 1-14. Chicago - London: University of Chicago Press.

Markham, Annette N.

2013 Fieldwork in Social Media. What Would Malinowski Do? Journal of Qualitative Communication Research 2(4):434-446.

Mazzucato, Valentina

2009 Bridging Boundaries with a Transnational Research Approach: A Simultaneous Matched Sample Methodology. In Falzon, Mark-Anthony (ed.) Multi-Sited Ethnography. Theory, Praxis and Locality in Contemporary Research, 215232. Farnham - Burlington: Ashgate.

Miller, Daniel

2012 Social Networking Sites. In Horst, Heather H. - Miller, Daniel (eds.) Digital Anthropology, 146-164. London - New York: Berg.

Miller, Daniel - Horst, Heather H.

2012 The Digital and the Human: A Prospectus for Digital Anthropology. In Horst, Heather H. - Miller, Daniel (eds.) Digital Anthropology, 3-38. London New York: Berg.

Miller, Daniel - Slater, Don

2001 The Internet: An Ethnographic Approach. Oxford - New York: Berg.

NADAi, Eva - MaEder, Christoph

2005 Fuzzy Fields. Multi-Sited Ethnography in Sociological Research. Forum Qualitative Social Research 6(3). http://www.qualitative-research.net/index. php/fqs/article/view/22/47 (accessed February 18, 2016)

NAGY, Károly Zsolt

2012 'Hová lett a református öntudat?' A magyar református felekezeti identitás megújításának néhány diskurzusáról ['What Has Become of Reformed Consciousness?' On Some of the Discourses on the Renewal of the Reformed Hungarian Identity]. Doctoral dissertation. Pécs: University of Pécs, 
Faculty of Humanities, Doctoral School of Linguistics, Doctoral Program in Communication.

PrónAI, Csaba

2002 Migráció és kulturális antropológia (Tudománytörténeti vázlat) [Migration and Cultural Anthropology (A Scientific-Historical Outline)]. In Kovács, Nóra - Szarka, László (eds.) Tér és terep. Tanulmányok az etnicitás és az identitás kérdésköréböl, 347-366. Budapest: Akadémiai kiadó.

SANDU, Dumitru

2006 Expolatarea Europei prin migraţii pentru muncă: 1990-2006 [Exploitation of Europe through labor migration: 1990-2006]. In SANDU, Dumitru (ed.) Locuirea temporară în străinătate. Migrație economică a românilor: 19902006, 17-39. Bucureşti: Fundaţia Pentru o Societate Deschisă.

TÁnczos, Vilmos

1996 Kitántorgott... Magyarországra. Egy társasutazás margójára [He Staggered to... Hungary. To the Margins of a Package Tour]. In Tánczos, Vilmos: Keletnek megnyilt kapuja. Néprajzi esszék, 16-41. Kolozsvár: KOM-PRESS, Ariadné Könyvek.

Vörös, Miklós - FRIDA, Balázs

$2005 \mathrm{Az}$ antropológiai résztvevő megfigyelés története [The History of Anthropological Participant Observation]. In LetenYeI, László (ed.) Településkutatás. A települési és térségi tervezés társadalomtudományos alapozása. Módszertani szöveggyüjtemény, 395-416. Budapest: L’HarmattanRáció Kiadó.

WeIBKÖPPEL, Cordula

2009 Traversing Cultural Sites: Doing Ethnography among Sudanese Migrants in Germany. In Falzon, Mark-Anthony (ed.) Multi-Sited Ethnography. Theory, Praxis and Locality in Contemporary Research, 251-270. Farnham Burlington: Ashgate.

Tünde Turai is a senior research fellow at the Institute of Ethnology, RCH, HAS. Her principal research topics are the elderly generation, the family, migration, care for elderly people, and transboundary regions. She carries out fieldwork in post-communist societies in Central and Eastern Europe, as well as regions that are the destinations of the biggest numbers of migrants from these societies. Her monograph on the topic discussed in this article was published in 2018. E-mail: turai.tunde@btk.mta.hu 